\title{
DNA Fingerprinting Reveals Polygyny in the Lesser Kestrel (Falco naumanni)
}

\author{
José L. Tella, ${ }^{1}$ Juan J. Negro, ${ }^{2}$ Morris Villarroel,${ }^{2}$ URS Kuhnlein, ${ }^{3}$ \\ FERNANDO Hiraldo, ${ }^{1}$ JosÉ A. DONÁzAR, ${ }^{1}$ AND DAVID M. BIRD ${ }^{2}$ \\ ${ }^{1}$ Estación Biológica de Doñana, CSIC, Apdo. 1056, 41080 Sevilla, Spain; \\ ${ }^{2}$ Avian Science and Conservation Centre, McGill University, Ste. Anne de Bellevue, Quebec H9X 3V9, Canada; and \\ ${ }^{3}$ Department of Animal Science, McGill University, Ste. Anne de Bellevue, Quebec H9X 3V9, Canada
}

Diurnal birds of prey are predominantly monogamous (Newton 1979, Faaborg and Bednarz 1990). However, some species have adopted alternative mating systems, such as polygyny, polyandry or cooperative breeding (Newton 1979, Faaborg and Bednarz 1990, Heredia and Donázar 1992, Tella 1993). Polygamous trios have been observed in at least 11 raptor species, but confirmation of polygamy through paternity analysis has only been reported for the Galapagos Hawk (Buteo galapagoensis; Faaborg et al. 1995). These kinds of studies also are scarce in other bird species, where polygyny occurs more frequently (but see Gibbs et al. 1990, Gyllensten et al. 1990, Dunn and Robertson 1993, Pinxten et al. 1994).

The Lesser Kestrel (Falco naumanni) is a colonially nesting, socially monogamous falcon. Some individuals, mostly males, are known to engage in extrapair copulations (Negro et al. 1992), although the incidence of extrapair fertilizations is low (Negro et al. in press). Males mated with two females early in the breeding season have been reported, but those polygynous trios disbanded before egg laying (Hiraldo et al. 1991, Tella unpubl. data). Nonetheless, supernormal clutches have also been observed (Hiraldo et al. 1991) and, thus, successful bigamy or intraspecific brood parasitism is strongly suspected. Here, we report a case in Lesser Kestrels where two females laid eggs in the same nest. DNA-fingerprinting analysis showed that the attending male fathered all four nestlings and that the two attending females were the mothers of one and three nestlings, respectively.

Methods. - Our study was carried out in 1993 in Los Monegros, northeastern Spain $\left(41^{\circ} 25^{\prime} \mathrm{N}, 0^{\circ} 11^{\prime} \mathrm{E}\right)$, where a population of 230 pairs of Lesser Kestrel bred in 49 colonies located in abandoned farmhouses (Tella et al. in press). Lesser Kestrels are migratory and spend the winter in Africa (Cramp and Simmons 1980). Individuals return to the colonies in late February and throughout March. In 1991, the average egg-laying date was 7 May $(n=199)$. At different times during the breeding period, adult Lesser Kestrels $(n=270)$ were caught at night while roosting in their nests. All birds were banded with color-numbered PVC bands for identification by telescope (Donázar et al. 1992, Negro et al. 1992). Adult males were assigned to two age categories-yearling and $\geq 2$ years oldaccording to plumage (Cramp and Simmons 1980). Blood samples were taken from most adult birds, as well as from the offspring at selected nests that were monitored periodically to determine clutch and brood size.

About $0.4 \mathrm{ml}$ of blood taken from the brachial vein was preserved in a lysis buffer (Seutin et al. 1991) that permitted its transport and temporary storage at room temperature. DNA analyses were conducted in the Animal Science Department of McGill University in Montreal, Canada. Aliquots of the samples $(0.25 \mathrm{ml})$ were mixed with $5 \mathrm{ml}$ of $1 \times$ SSC and centrifuged at $7,000 \mathrm{rpm}$ for $15 \mathrm{~min}$. The resulting pellet was resuspended in $2 \mathrm{ml}$ of $0.2 \mathrm{M}$ sodium acetate and 100 $\mu \mathrm{l}$ of $20 \%$ SDS. We extracted the samples with $2 \mathrm{ml}$ of a mixture consisting of equal parts of phenol and chloroform:isoamyl alcohol (24:1). The samples were centrifuged at $2,000 \mathrm{rpm}$ for $20 \mathrm{~min}$, and the supernatant was subjected to a second extraction. The DNA was precipitated with cold ethanol and preserved in $0.5 \mathrm{ml}$ of $5 \mathrm{mM}$ Tris $\mathrm{HCl}, 0.1 \mathrm{mM}$ EDTA. Aliquots of $5 \mu \mathrm{g}$ of DNA were digested with the restriction enzyme HinfI and subjected to electrophoresis on 20$\mathrm{cm}$-long $0.7 \%$ agarose gels at $29 \mathrm{~V}$ for $36 \mathrm{~h}$. The gels were dried in a vacuum gel dryer and hybridized in situ with a mixture consisting of $5 \times$ SSPE, $5 \times$ Denhardt's solution, $10 \mu \mathrm{g} / \mathrm{ml}$ of herring sperm DNA and $1-2 \times 10^{6} \mathrm{cpm} / \mathrm{ml}$ of the oligonucleotide probe $(\text { GGAT })_{4}$ labeled with [ $\gamma^{32}$ P]ATP. We used T4 polynucleotide kinase for labeling. The gels were hybridized overnight and then washed twice for $30 \mathrm{~min}$ with $6 \times$ SSC at room temperature. Autoradiography was conducted at room temperature for three to four days. More details on the hybridization procedure and the use of (GGAT) $)_{4}$ are given in Wolfes et al. (1991) and Negro et al. (in press).

Comparisons of banding patterns were confined to lanes on the same gel. Parentage was determined by band-exclusion analysis (Decker et al. 1993, Sheldon. and Burke 1994). Bands in the offspring's fingerprint were matched to bands present in the parents. The presence/absence of unattributable bands is the primary basis for determining parentage. In addition, band-sharing coefficients (BSC; i.e. proportion of bands in fingerprint shared by any two given individuals) were calculated. In our population, the "background" BSC is 0.21 (Negro et al. in press) and, thus, the expected BSC (Lynch 1991) for first-order relatives is 0.60 . We used as the threshold limit for parentage exclusion the lower $95 \%$ confidence limit $(B S C=0.324$ ) of the BSC distribution for first-order relatives (Decker et al. 1993, Sheldon and Burke 1994). 


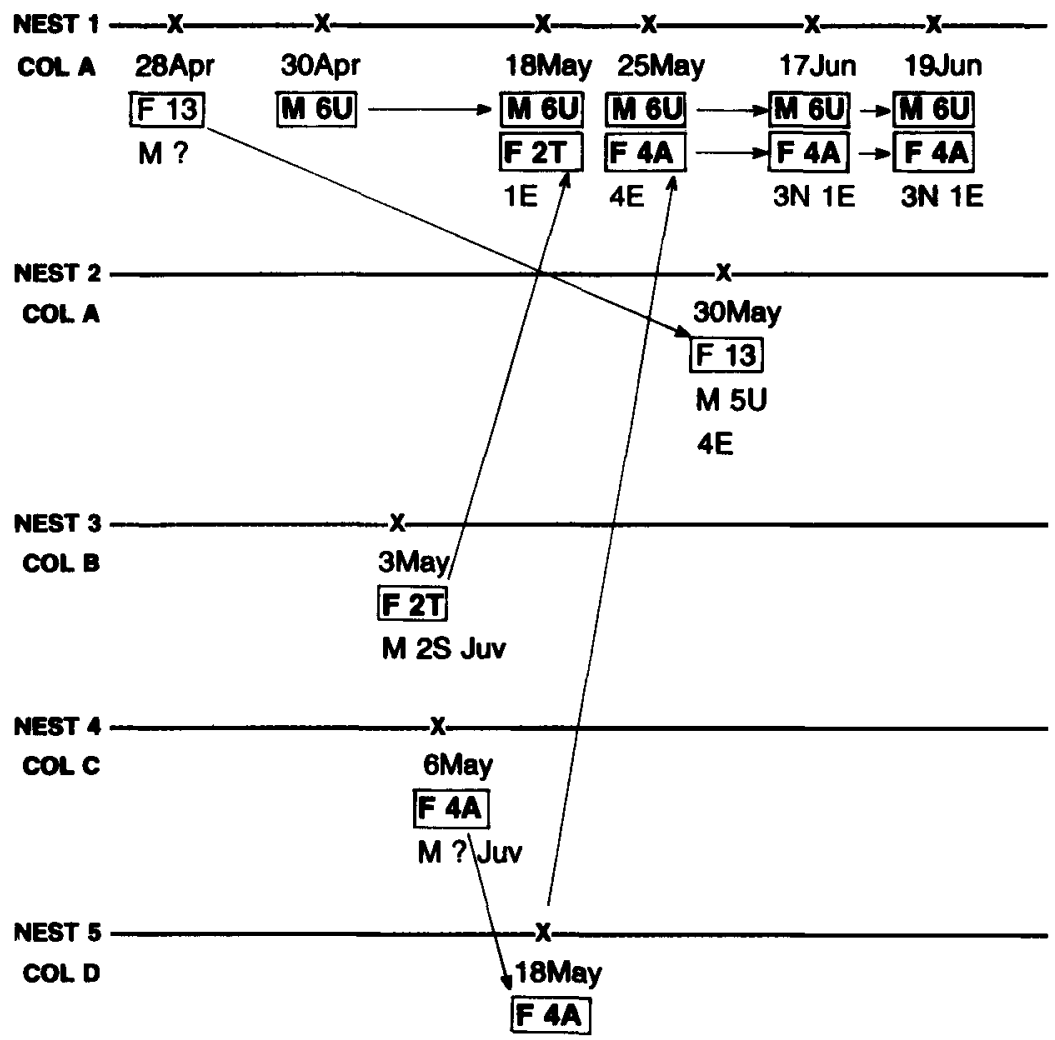

Fig. 1. Breeding chronology of Lesser Kestrels involved in polygynous case. Codes used: $(M)$ male; $(F)$ female; (E) number of eggs; (N) number of nestlings; (Y) yearling; (M?) unidentified male; (COL) colony; (13, $6 \mathrm{U}, 2 \mathrm{~T}$, and $4 \mathrm{~A}$ ) band numbers. Band numbers of polygynous birds are in bold.

Results. - The breeding chronology of the birds involved in this case of polygyny is shown in Figure 1. Nest 1, previously occupied by a pair of Lesser Kestrels, was defended by male $6 \mathrm{U}$ ( $\geq 2$ years old) at the end of April. In early May, male $6 U$ and female $2 \mathrm{~T}$ attended the nest, which contained a single egg that we marked and measured. One week later the nest contained four eggs, including the one marked in the previous visit, and there was a new attending female, $4 \mathrm{~A}$. No differences in coloration or measurements were found among the eggs. Remains of other eggs were not found in or around the nest. The resulting clutch of four eggs was not much different from the average clutch of $4.45 \pm \mathrm{SD}$ of $0.74 \mathrm{eggs}$ in the population in $1993(n=114)$. In two subsequent visits, only female $4 \mathrm{~A}$ was observed at the nest (Fig. 1). Female $2 T$ was not seen again during the rest of the 1993 breeding season, but she was resighted as a breeder in the study area in 1995.

The interval between the time the egg was laid by female $2 \mathrm{~T}$ and when the first egg was laid by female $4 \mathrm{~A}$ was one to three days. This was estimated from the dates the females were captured taking into account the typical laying interval between consecutive eggs of two days (Cramp and Simmons 1980). Measurements of the nestlings' eighth primary feather were used to age the birds (Donázar et al. 1991) and indicated that the older three young hatched within $24 \mathrm{~h}$, and that the remaining egg hatched three to four days later. These results may be attributable to the fact that females usually start incubation after laying the third egg (Negro et al. 1991). All of the hatchlings fledged.

The two females that mated with male $6 \mathrm{U}$ had previously been paired with yearling males (Fig. 1). Why the females broke up with those males is unknown, although in the case of female $2 \mathrm{~T}$ it could be related to fox predation and the subsequent desertion of the colony by the survivors.

Female 13, the bird that was first associated to nest 1 , mated later with male $5 \mathrm{U}$ and attended nest 2 in the same colony (Table 1). DNA fingerprinting demonstrated that female 13 and male $5 U$ were the parents of the nestlings in nest 2 .

The band-exclusion analysis and band-sharing coefficients indicate that male $6 \mathrm{U}$ was the father of all nestlings, while female $2 \mathrm{~T}$ was the mother of the older nestling, and female $4 \mathrm{~A}$ was the mother of the 
TABLE 1. Results of the band-exclusion analysis. Proportion of nestling bands not present in male $6 \mathrm{U}$ and female indicated.

\begin{tabular}{ccc}
\hline \hline Nestling & Female 2T & Female 4A \\
\hline 1 & $0 / 8$ & $3 / 8$ \\
2 & $2 / 9$ & $0 / 9$ \\
3 & $4 / 8$ & $0 / 8$ \\
4 & $2 / 7$ & $0 / 7$ \\
\hline
\end{tabular}

remaining three nestlings. There were no unattributable bands when the correct female was included in the comparison (Table 1). Band-sharing coefficients for all pairwise combinations of adults and nestlings are given in Table 2. Values for nestlings and their assigned parents, as well as those for true siblings, are above of the threshold limit for parentage exclusion, and the mean $(0.534 \pm 0.14, n=11)$ is close to 0.6 , the expected BSC value for first-order relatives in our population.

Discussion.-Mixed maternity in broods or clutches has been documented by molecular markers in several bird species and, usually, has been interpreted as the result of intraspecific brood parasitism (Pinxten et al. 1993, Avise 1994, Meek et al. 1994, Negro et al. in press). We ruled out this hypothesis because the attending male was related to all chicks in the brood. Other possible causes of multiple maternity could be: (1) quasiparasitism (Petrie and Møller 1991, Birkhead et al. 1990), in which the eggs dumped by the parasitic female were fertilized by the nest-attending male; (2) mate replacement of the female that laid eggs first; and (3) polygyny, in which two or more females lay eggs and provide parental investment.

Given that female 2T laid first and at a time when female $4 \mathrm{~A}$ was in a different colony more than $1 \mathrm{~km}$ away (see Table I), our case of multiple maternity can hardly be a case of quasiparasitism. Rather, it is a case in which two females fertilized by the same male laid eggs in the same nest. We can discard the hypothesis that mate replacement took place due to death of the first laying female, but we cannot exclude replacement due to desertion or displacement (Choudhury 1995) of female 2T. Given that our nest monitoring was not intensive, it is also possible that females $2 \mathrm{~T}$ and $4 \mathrm{~A}$ participated in the incubation and chick rearing in nest 1 . Although rare and usually unsuccessful, nest-sharing polygyny has been observed in raptors (Newton 1979, Poole 1989). Among other species of birds, nest-sharing polygyny has been documented by DNA analysis in the European Starling (Sturnus vulgaris; Pinxten et al. 1994).

The aborted polygynous trios observed by Hiraldo et al. (1991) started 50 to 70 days before the primary female laid eggs. In our case, however, polygyny occurred precisely at laying time. The two females previously had been at different colonies paired to year-
TABLE 2. Band-sharing coefficients for all pairwise combinations of three adult Lesser Kestrels and the four nestlings in the nest."

\begin{tabular}{lcccccc}
\hline \hline \multicolumn{1}{c}{ Bird } & 2T & 4A & 1 & 2 & 3 & 4 \\
\hline Male 6U & 0.11 & 0.31 & 0.73 & 0.33 & 0.44 & 0.35 \\
Female 2T & & 0.11 & 0.62 & 0.11 & 0.00 & 0.13 \\
Female 4A & & & 0.23 & 0.55 & 0.70 & 0.65 \\
Nestling 1 & & & & 0.23 & 0.25 & 0.26 \\
Nestling 2 & & & & & 0.35 & 0.50 \\
Nestling 3 & & & & & 0.66 \\
\hline
\end{tabular}

"Female $2 \mathrm{~T}$ is mother of nestling $\mathrm{l}$, whereas female $4 \mathrm{~A}$ is mother of nestlings 2, 3 and 4 .

ling males. The reproductive value of these males is much lower than that of older males (Negro 1991, Hiraldo et al. unpubl. manuscript), and the females may have deserted them to pair with a better male. The bigamous male, in turn, apparently was unpaired but attending the nest site at the beginning of the laying period. Even though the polygyny attempt started late in the season, it may have been successful because food conditions were favorable. In fact, breeding success in our population in 1993 (Tella et al. in press) was almost double as the one reported by Hiraldo et al. (1991).

The results of a broader paternity study in our population (Negro et al. in press) indicate that polygyny occurred in 1 of 27 families. Thus, the frequency of polygamous matings in the population was probably low. This polygyny case could have easily passed unnoticed without repeated nest visits or if molecular markers had not been used.

Acknowledgments. - We thank R. López and M. Pomarol for help in the fieldwork, and P. Dunn, I. Warkentin, G. D. Schnell, and an anonymous referee for their comments on the manuscript. The CICYT (Project PB 90-1021) provided financial support. J.L.T. was supported by a FPI Predoctoral Fellowship of the Spanish Ministerio de Educación y Ciencia. J.J.N. beneffited from a Postdoctoral Fellowship of the CSIC. A NATO collaborative grant provided travel assistance.

\section{LiTERATURE CITED}

AvisE, J. 1994. Molecular markers, natural history and evolution. Chapman and Hall, New York.

BIRKHEAD, T. R., T. BURKE, R. ZANN, F. M. HUNTER, AND A. P. KRUPA. 1990. Extra-pair paternity and intraspecific brood parasitism in wild Zebra Finches Taenopygia guttata, revealed by DNA fingerprinting. Behav. Ecol. Sociobiol. 27:315-324.

Choudhury, S. 1995. Divorce in birds: A review of the hypothesis. Anim. Behav. 50:413-429.

Cramp, S., AND K. E. L. Simmons. 1980. The birds of the western Palearctic, vol. 2. Oxford Univ. Press, Oxford. 
DeCKer, M. D., P. G. PARKer, D. J. Michella, AND K. N. RABENOLD. 1993. Monogamy in Black Vultures: Genetic evidence from DNA fingerprinting. Behav. Ecol. 4:29-35.

Donázar, J. A., J. J. Negro, ANd F. Hiraldo. 1991. A note on the adoption of alien young by Lesser Kestrels Falco naumanni. Ardea 79:443-444.

Donázar, J. A., J. J. Negro, and F. Hiraldo. 1992. Functional analysis of mate-feeding in the Lesser Kestrel Falco naumanni. Ornis Scand. 23:190-194.

DunN, P. O., AND R. J. RoBERTSON. 1993. Extra-pair paternity in polygynous Tree Swallows. Anim. Behav. 45:231-239.

FAABORG, J., AND J. C. BEDNARZ. 1990. Galapagos and Harris' hawks: Divergent causes of sociality in two raptors. Pages 359-383 in Cooperative breeding in birds (P. B. Stacey and W. D. Koenig, Eds.). Cambridge Univ. Press, Cambridge.

FaAborg, J., P. G. Parker, L. Delay, T. J. De VRies, J C. Bednarz, S. Maria Paz, J. Naranjo, aND T. A. WAITE. 1995. Confirmation of cooperative polyandry in the Galapagos Hawk (Buteo galapagoensis). Behav. Ecol. Sociobiol. 36:83-90.

Gibbs, H. L., P. J. Weatherhead, P. T. Boag, B. N. WhITE, L. M. TABAK, AND D. J. HoYSAK. 1990. Realized reproductive success of polygynous Redwinged Blackbirds revealed by DNA markers. Science 250:1394-1397.

GYllensten, U. B., S. JAKOBSSON, AND H. TEMRIN. 1990. No evidence for illegitimate young in monogamous and polygynous warblers. Nature 343 : 168-170.

Heredia, R., AND J. A. Donazar. 1990. Polyandrous trios in an endangered population of Lammergeiers Gypaetus barbatus in northern Spain. Biol. Conserv. 53:63-71.

Hiraldo, F., J. J. Negro, and J. A. Donazar. 1991. Aborted polygyny in the Lesser Kestrel Falco naumanni (Aves, Falconidae). Ethology 89:253-257.

LYNCH, M. 1991. Analysis of population genetic structure by DNA fingerprinting. Pages 113-126 in DNA fingerprinting: Approaches and applications (T. Burke, G. Dolf, A. J. Jeffreys, and R. Wolf, Eds.). Birkhauser Verlag, Basel.

MEEK, S. B., R. J. ROBERTSON, AND P. T. BOAG. 1994. Extrapair paternity and intraspecific brood parasitism in Eastern Bluebirds revealed by DNA fingerprinting. Auk 111:739-744.

NeGro, J. J. 1991. Ecología de poblaciones del Cer- nicalo Primilla Falco naumanni. Ph.D. dissertation, Univ. Sevilla, Sevilla, Spain.

Negro, J. J., J. A. Donazar, and F. Hiraldo. 1992. Copulatory behaviour in a colony of Lesser Kestrels: Sperm competition and mixed reproductive strategies. Anim. Behav. 43:921-930.

Negro, J. J., M. Villarroel, J. L. Tella, U. KuHNLEIN, F. Hiraldo, J. A. Donazar, and D. M. Bird. In press. DNA fingerprinting reveals a low incidence of extra-pair fertilizations in the Lesser Kestrel. Anim. Behav.

Newton, I. 1979. Population ecology of raptors. T \& A.D. Poyser, London.

Petrie, M., AND A. P. Møller. 1991. Laying eggs in other's nests: Intraspecific brood parasitism in birds. Trends Ecol. \& Evol. 6:315-320.

PinXTEN, R., O. HANOTte, M. Eens, R. F. VeRheYen, A. A. DHONDT, AND R. F. VERHEYEN. 1993. Extrapair paternity and intraspecific brood parasitism in the European Starling, Sturnus vulgaris: Evidence from DNA fingerprinting. Anim. Behav. 45:705-809.

PinXTEN, R., M. EENS, AND R. F. VerHeYen. 1994. Communal breeding in the European Starling: Evidence from DNA fingerprinting. Auk 111:482486.

Poole, A. F. 1989. Ospreys. A natural and unnatural history. Cambridge Univ. Press, Cambridge.

Seutin, G., B. N. White, and P. T. Boag. 1991. Preservation of avian blood and tissue samples for DNA analyses. Can. J. Zool. 69:82-90.

SHELdON, B. C., AND T. BuRKE. 1994. Copulation frequency and paternity in the Chaffinch. Behav. Ecol. Sociobiol. 34:149-156.

Tella, J. L. 1993. Polyandrous trios in a population of Egyptian Vultures. J. Raptor Res. 27:119-20.

Tella, J. L., F. Hiraldo, J. A. Donazar, and J. J. NEGro. In press. Costs and benefits of urban nesting in the Lesser Kestrel (Falco naumanni). In Raptors in human landscapes (D. M. Bird, D. Varland, and J. J. Negro, Eds.). Academic Press, New York.

Wolfes, R., J. MATHE, AND A. SEITZ. 1991. Forensics of birds of prey DNA fingerprinting with ${ }^{32} \mathrm{P}$ labeled oligonucleotide probes. Electrophoresis 12:175-180.

Received 20 December 1994, accepted 8 March 1995. 